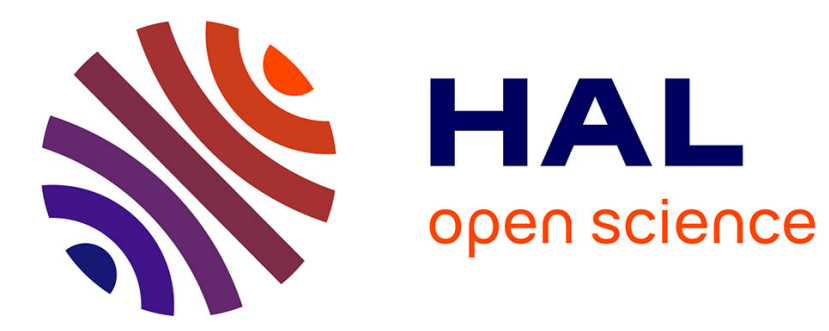

\title{
Social Entrepreneurship in Sub-Saharan Africa
}

Miguel Rivera-Santos, Diane Holt, David Littlewood, Ans Kolk

\section{To cite this version:}

Miguel Rivera-Santos, Diane Holt, David Littlewood, Ans Kolk. Social Entrepreneurship in SubSaharan Africa. Academy of Management Perspectives, 2015, 29 (1), 72-91 p. hal-02276715

\section{HAL Id: hal-02276715 https://hal.science/hal-02276715}

Submitted on 3 Sep 2019

HAL is a multi-disciplinary open access archive for the deposit and dissemination of scientific research documents, whether they are published or not. The documents may come from teaching and research institutions in France or abroad, or from public or private research centers.
L'archive ouverte pluridisciplinaire HAL, est destinée au dépôt et à la diffusion de documents scientifiques de niveau recherche, publiés ou non, émanant des établissements d'enseignement et de recherche français ou étrangers, des laboratoires publics ou privés. 


\title{
$\begin{array}{lllllllll}S & \mathrm{Y} & \mathrm{M} & \mathrm{P} & \mathrm{O} & \mathrm{S} & \mathrm{I} & \mathrm{U} & \mathrm{M}\end{array}$
}

\section{SOCIAL ENTREPRENEURSHIP IN SUB-SAHARAN AFRICA}

\author{
MIGUEL RIVERA-SANTOS \\ Babson College \\ DIANE HOLT \\ Essex Business School \\ DAVID LITTLEWOOD \\ Henley Business School \\ ANS KOLK \\ University of Amsterdam Business School
}

\begin{abstract}
Responding to calls for a better understanding of the relationship between social enterprises and their environments, this article focuses on contextual influences on social entrepreneurship in sub-Saharan Africa. We identify four predominantly African contextual dimensions (acute poverty, informality, colonial history, and ethnic group identity) and explore their influence on the way social ventures perceive themselves and on their choice of activities. Our empirical study of 384 social enterprises from 19 sub-Saharan African countries suggests that ethnic group identity and acute poverty levels influence both self-perception and activity choices, the country's colonial history influences only self-perception, and informality has no significant influence on either. These findings point to the need to consider both self-perception and the choice of activities in defining social entrepreneurship. Our study also highlights the importance of African contextual dimensions for understanding social entrepreneurship, and underlines the added value of incorporating insights from African data into management research more broadly.
\end{abstract}

While most scholars agree that what differentiates social enterprises from their commercial counterparts is the fact that they combine profitability and social/environmental goals (Dacin, Dacin, \& Tracey, 2011; Doherty, Haugh, \& Lyon, 2014; Pless, 2012), what social entrepreneurship actually en-

The authors contributed equally to the paper.

The authors would like to thank the editor and the anonymous reviewers for their constructive feedback. The authors would also like to thank Aldas Kriauciunas and Anne Parmigiani for their comments on earlier versions of the paper. The financial support of the Economic and Social Research Council (RES-061-25-0473 awarded to principal investigator Diane Holt) is gratefully acknowledged. Further information on the Trickle Out Africa Project can be found at www.trickleout.net. tails is still the subject of heated debate. In particular, there remains disagreement among scholars regarding definitional boundaries and the dimensions along which these enterprises should be identified and analyzed (Dacin et al., 2011; Mair \& Martí, 2006; Santos, 2012; Zahra, Gedajlovic, Neubaum, \& Shulman, 2009). These debates are not purely academic, as they also have significant implications for policy (Leadbeater, 2007). Different scholars have used varied approaches to tackle this question, ranging from calls for theory-based rather than practice-based definitions (Mair \& Martí, 2006) to arguments that some definitional differences may come from the coexistence of competing schools of thought in the literature (Bacq \& Janssen, 2011).

In this debate, scholars have highlighted several dimensions as particularly relevant, with impor- 
tant implications for the definition of social entrepreneurship. Self-perception as a social enterprise, for instance, is commonly used in empirical studies to identify social enterprises or social entrepreneurs (Lyon, Teasdale, \& Baldock, 2010; Mair, Battilana, \& Cardenas, 2012; Meyskens, Robb-Post, Stamp, Carsrud, \& Reynolds, 2010), suggesting that the fact that individuals consider their venture to be a social enterprise is key to understanding its mission and activities. Similarly, some scholars have analyzed the choice of activities as well as the patterns of profit distribution as a way to assess the coexistence of social and profitability goals and thus determine the social entrepreneurial nature of a venture (Doherty et al., 2014; Santos, 2012; Zahra et al., 2009). Other scholars stress the diversity that exists across social enterprises, leading to the development of typologies based on a variety of dimensions (e.g., Mair et al., 2012; Zahra et al., 2009).

Reviewing this literature, however, Bacq and Janssen (2011) found that, among the different relevant dimensions that could affect social enterprises, the characteristics of the environment (i.e., the context in which the venture operates) have received very limited attention, despite early acknowledgments of their importance for social entrepreneurs (e.g., Mair \& Martí, 2006). At a basic level, the environment creates the social needs and thereby the social opportunities that entrepreneurs or their agents can pursue (Santos, 2012). It also determines the legal recognition and forms of social enterprises, with important variations found across different countries (Defourny \& Nyssens, 2008; Kerlin, 2006; Peattie \& Morley, 2008).

At a deeper level, characteristics of the environment are likely to affect not only the possible emergence of social enterprises, but also many of the characteristics of these ventures. For instance, scholars have highlighted the importance for social enterprises of the effectiveness of government actions and quality of infrastructures (Partzsch \& Ziegler, 2011; Santos, 2012), of formal and informal institutions (Rivera-Santos, Rufín, \& Kolk, 2012), of cultural preferences for individual or collective action (Montgomery, Dacin, \& Dacin, 2012), and of the extent to which compassion will be transformed into social entrepreneurial initiatives in different institutional environments (Miller, Grimes, McMullen, \& Vogus, 2012). A better understanding of how the environment affects different dimensions of social enterprises, therefore, seems essential.
In this paper, we take a first step in addressing this gap with a study of sub-Saharan African social enterprises. We seek to answer this research question: How do contextual dimensions influence social entrepreneurship in sub-Saharan Africa? The African continent provides a particularly apt illustration of how an environment can influence social entrepreneurial ventures. Despite variation across and within them, countries in sub-Saharan Africa are typically characterized by high levels of poverty, with 26 countries ranked among the 30 poorest countries in the world (International Monetary Fund, 2013); government failures, with 14 countries ranked among the 30 most corrupt countries in the world (Transparency International, 2012); and poor infrastructure, market failures, and a large informal economy, with 23 countries ranked among the 30 worst countries to do business in (World Bank, 2012). Furthermore, the African institutional environment is characterized by lingering colonial influences (Acemoglu, Johnson, \& Robinson, 2000) and by particularly strong ethnic group identities (Michalopoulos \& Papaioannou, 2015; Nyambegera, 2002), setting it apart from other developing country contexts. The sub-Saharan African environment is thus likely to create many opportunities for social enterprises to emerge in new and creative forms that reflect this institutional variability and these constraints.

Grounding our reasoning in institutional theory, we identify four predominantly African contextual dimensions-(1) acute poverty, (2) informality, (3) colonial history, and (4) ethnic group identity-and explore their influence on the way social ventures perceive themselves and on their choice of activities. We do so through an empirical study of 384 social enterprises from 19 sub-Saharan African countries. Our results suggest that ethnic group identity and acute poverty influence both self-perception and activity choices, the country's colonial history influences only self-perception, and informality has no significant influence on social entrepreneurship.

Our contributions are threefold. First, we underscore how environmental characteristics affect the self-perception as, and the actual activities of, social enterprises. In so doing, we take a first step in responding to calls for a better understanding of the relationship between social enterprises and their environment (Bacq \& Janssen, 2011; Mair \& Martí, 2006). Second, our findings show that there is a conceptual and empirical difference between selfperception and the activities of social enterprises, 
suggesting that caution is needed when equating self-identification as a social enterprise and an actual social mission on the ground. This study thus contributes to the debate around the definition of social entrepreneurship by emphasizing the need to consider both self-perceptions and activities to define a social entrepreneurial venture. Third, our exploratory analysis of sub-Saharan African social enterprises not only helps expand our knowledge of such organizations in these settings, but also highlights the insights that African data can bring to the social entrepreneurship literature, thus responding to calls for an incorporation of African insights into the academic debate in management (Zoogah, 2008; Zoogah \& Nkomo, 2013).

The paper is organized as follows: We start with a discussion of the social entrepreneurship literature and insights offered on boundaries and characteristics. This is followed by a presentation of the specificities of the African environment, considering the socioeconomic and historico-political contextual dimensions. Building on these foundations, the subsequent section links the specific characteristics of the sub-Saharan African context with selfperceptions and activities of social entrepreneurial ventures, and discusses the key findings of our empirical study of social enterprises in 19 African countries that allow us to disentangle these relationships (the full details of the study are included in the appendix). The final section discusses the implications of our research for the social entrepreneurship literature and the management field more broadly.

\section{SOCIAL ENTERPRISES AND THEIR CHARACTERISTICS}

Beyond the agreement that a social enterprise combines profitability with social/environmental objectives (Doherty et al., 2014)—which, some authors argue, is a tautology rather than a definition (Cho, 2006; Parkinson \& Howorth, 2008)-there is little consensus on boundaries and characteristics of social enterprises. Similar ambiguity exists in relation to social entrepreneurship, and as a result, definitions abound, leading authors to characterize it as an essentially contested concept (Choi \& Majumdar, 2014) and the field as a whole as pre-paradigmatic (Lehner \& Kansikas, 2013). Interestingly, these debates are also important in practitioners' discussions of social enterprises and entrepreneurship (Financial Times, 2013), suggesting that these definitional issues are not just academic concerns. To clarify these boundaries, researchers have used several different approaches, including the development of theorydriven definitions, the identification of several schools of thought in the literature to explain variations across definitions, empirical and conceptual typologies, and exploration of the different dimensions of social entrepreneurship.

Responding to calls for a grounding in the broader management literature as a way to go beyond practice-driven definitions that may reflect specific cases (Mair \& Martí, 2006), some authors have developed conceptual frameworks to understand social entrepreneurship and social enterprises in light of existing theories. Santos (2012), in particular, contended that there is a conceptually distinct domain for social entrepreneurship. He argued that there are specific situations in which social entrepreneurial activity can be expected to emerge and that social entrepreneurship scholars can therefore define social enterprises as being created to respond to a particular type of situation. Highlighting the trade-off that exists between value creation and value capture in the combination of social and commercial goals, he contended that social enterprises can be expected to emerge in contexts of simultaneous market and government failures, concluding that "social entrepreneurship is the pursuit of sustainable solutions to neglected problems with positive externalities" (Santos, 2012, p. 335). Similarly, Miller and colleagues (2012) highlighted the importance of compassion and pro-social motivations to understand social ventures, arguing that three mechanisms (integrative thinking, pro-social cost-benefit analysis, and commitment to alleviating others' suffering) can explain the transformation of compassion into social entrepreneurship and identify the institutional conditions in which this transformation is most likely to occur. Interestingly, both perspectives highlight the importance of interactions between social enterprises and their broader economic and institutional environments.

Other authors have argued that the definitional differences that can be seen in the literature may not reflect the social enterprises themselves, but, rather, the scholarly approaches taken to analyze them. Bacq and Janssen (2011), for instance, identified three main schools of thought in the literature: the social innovation school, with a strong focus on the entrepreneur; the social enterprise school, in which the entrepreneur 
takes a secondary role, superseded by the role of nonprofit organizations or states; and the EMES (Emergence of Social Enterprises in Europe) school, which emphasizes collective action and is more prevalent among European scholars. Here again, these authors highlight the importance of the environment in which social enterprises evolve.

Arguing that one-size-fits-all definitions may not accurately reflect the complexity of social enterprises and entrepreneurship, other authors have approached these definitional issues through the development of typologies based on the different definitions that exist in the literature. Dacin, Dacin, and Matear (2010), for instance, identified 37 different definitions and explored what may be unique about the concept of social entrepreneurship. The authors concluded that social entrepreneurship cannot be considered as distinct from the broader concept of entrepreneurship, but that the specific context in which social entrepreneurs and their ventures operate provides interesting avenues for research. By contrast, Zahra and colleagues (2009) focused on the distinctive aspects of social entrepreneurship, drawing on 20 different social entrepreneurship definitions from academic and practitioner literature. They argued that social entrepreneurs can be seen as individuals pursuing a total wealth that combines economic and social wealth, with the authors defining social entrepreneurship as encompassing "the activities and processes undertaken to discover, define, and exploit opportunities in order to enhance social wealth by creating new ventures or managing existing organizations in an innovative manner" (p. 522). Within this broad definition, the authors identified three different types of entrepreneurs: "social bricoleurs," "social constructionists," and "social engineers," which they connect to three different intellectual traditions related to Hayek, Kirzner, and Schumpeter, respectively.

Using an empirical rather than a literature review-based approach, Mair and colleagues (2012) also developed a typology of social entrepreneurial ventures. They identified four types of social entrepreneurial ventures based on the four possible forms of capital that can be leveraged by the entrepreneur: social, economic, human, and political. The importance of the environment in which social enterprises are active is therefore also recognized in this approach. Different typologies highlight different dimensions, however.
Overall, the debate over the conceptual definition of social entrepreneurship is ongoing. Perhaps reflecting the essentially contested nature of the concept and the relative youth of social entrepreneurship as an academic field (Choi \& Majumdar, 2014; Lehner \& Kansikas, 2013), empirical studies tend to take a more inclusive approach. Many authors let social entrepreneurs self-identify (Mair et al., 2012; Meyskens et al., 2010; Santos, 2012) and thus rely on the entrepreneurs' perception of themselves and their ventures, while others analyze their activities on the ground instead. There are reasons to believe that self-perception and the social mission represented by the actual activities of the venture can vary across contexts, at the very least because of different national legal frameworks for social entrepreneurship (Defourny \& Nyssens, 2008; Kerlin, 2006; Mair \& Martí, 2006; Peattie \& Morley, 2008). In this context, it is surprising to see the limited attention paid to the impact of the environment on social entrepreneurship (Bacq \& Janssen, 2011), despite its implicit presence in definitions and debates throughout the literature, as noted above. In this paper, our goal is to contribute to this debate by specifically examining the influence of the environment on self-perception and the choice of activities, rather than by developing alternative definitions. To do so, we explore the characteristics of social enterprises in a little studied yet highly distinctive environment: sub-Saharan Africa. In the next section, we discuss the characteristics of this environment.

\section{THE SUB-SAHARAN AFRICAN ENVIRONMENT(S)}

While the African continent is now regularly presented as the next frontier for business (Economist, 2013), it is still very rarely studied in the management literature, leading to calls for more empirical research on Africa (Julian \& Ofori-Dankwa, 2013; Kolk \& Van Tulder, 2010; Zoogah \& Nkomo, 2013). In a review of 80 business and management journals from 1950 through 2011, Zoogah and Nkomo (2013) found only 216 articles focused on Africa and expressed regret that these studies do not show "the unique attributes of Africa that can be shared" (p. 19) across contexts. In areas of management that emphasize social issues, such as corporate responsibility, sustainable development, and social entrepreneurship, only a few studies use substantive multi-country African data that go beyond singlecountry cases and single-indicator set-ups (Egri \& Ralston, 2008; Kolk \& Van Tulder, 2010). In the area 
of business and poverty, Bruton (2010, p. 6) argued that "research in business in institutional settings where poverty is dominant remains very limited," a theme echoed by Kolk, Rivera-Santos, and Rufín (2014), who recommended widening the empirical contexts of base-of-the-pyramid research to better encompass Africa.

The African continent is characterized by serious social issues, which can become opportunities for business creation, combined with a lack of resources and poor governance, which are likely to present particular challenges for social entrepreneurs and enterprises. While these issues can be found in both developed and developing countries, recent research suggests important differences in the prominence of particular social and environmental issues within the public spheres of the Global North and South (Barkemeyer, Figge, \& Holt, 2013). The prevalence of social and environmental issues in sub-Saharan Africa, therefore, resonates with Santos's (2012) description of the conditions in which social entrepreneurship can be expected to emerge, and reinforces the need to examine the unique attributes of the African context.

Sometimes seen as a unit, sub-Saharan Africa comprises 50 countries, although the inclusion/ exclusion of some countries or areas, such as Sudan and the Indian Ocean islands, and the existence of internationally unrecognized secessions, such as Somaliland and Puntland, open this seemingly simple count to debate. Sub-Saharan African countries share commonalities, but they are also very different along substantial dimensions. In this section, we review socioeconomic and historico-political dimensions of subSaharan Africa, emphasizing not only the commonalities but also the variations across countries.

\section{Socioeconomic Contextual Dimensions}

Despite relatively high gross domestic product (GDP) growth rates, at $4.12 \%$ and $5.02 \%$ in 2011 and 2010, respectively (Trading Economics, 2013), sub-Saharan Africa is still characterized by severe socioeconomic problems. Of the 187 countries ranked by the International Monetary Fund (IMF) for GDP per capita in purchasing power parity terms, 26 sub-Saharan African countries are ranked in the bottom 30 (International Monetary Fund, 2013), with the Democratic Republic of the Congo, Zimbabwe, Burundi, Liberia, and Eritrea ranked as the five poorest countries in the world. Economic and social challenges are often compounded by conflicts, such as those in northern Mali, Somalia, Sudan, and the Democratic Republic of the Congo (Kolk \& Lenfant, in press), as well as by high economic inequality, with seven countries ranked among the 10 most unequal countries in the world (Vision of Humanity, 2012; World Bank, 2014), and by poor political governance and government failures (Bräutigam \& Knack, 2004) further exacerbating poverty. Multidimensional understandings of poverty (World Bank, 2000) incorporate not just economic components but also wider aspects of well-being, including health and education. The Education Index ranks 21 sub-Saharan African countries among the bottom 30 countries (UNDP, 2009). Similarly, among the 30 countries with the shortest life expectancy, 29 are sub-Saharan African countries (Das \& Samarasekera, 2012).

From an economic perspective, starting and growing businesses in sub-Saharan Africa is typically more difficult than in other parts of the world, linked to poor infrastructure, relative cost, and bureaucracy. The World Bank's ease of doing business ranking places 23 sub-Saharan African countries among the 30 worst (World Bank, 2012). Challenging business conditions alongside weak institutional structures lead to high levels of informality (De Soto, 2000; Godfrey, 2011), with important implications for management scholars (McGahan, 2012). For example, in this issue Zoogah, Peng, and Woldu (2015) discuss the influence of informal institutions and the importance of possessing informal resources and capabilities in the context of organizational effectiveness in Africa.

Estimates of the extent of the informal economy across the African continent are elusive, and coverage remains patchy. Current figures from the International Labor Organization (ILO) of the percentage of people employed in the informal economy cover only 10 sub-Saharan countries, and range from $33 \%$ (South Africa) to $70 \%$ (Zambia) (ILO, 2012). The ILO further reports that "cross-country data suggests that informal employment is paired with low income per capita and high poverty rates. . . . People in extreme poverty may have no other option than informal employment" (ILO, 2012, p. 3). This link may explain the prevalence of both poverty and informality in Africa.

Of course, alongside this somber picture is the story of Africa rising (Economist, 2011). Some subSaharan African countries exhibit high GDP growth rates despite global economic problems. In 2011, 
for example, Ghana grew by $14.4 \%$ and Liberia and Zimbabwe by $9.4 \%$ (World Bank, 2013), placing these countries among the 10 fastest growing economies in the world. Differences also exist within countries. Lagos in Nigeria, for instance, is the third fastest growing city in the world, with population growth of almost $50 \%$ in the first decade of the $21 \mathrm{st}$ century and concurrent rapid economic growth (Kotkin \& Cox, 2013), although World Bank data from 2010 indicates $82 \%$ of the population still live on less than $\$ 2$ per day. While high economic growth rates can sometimes be explained by raw material exports, in particular oil, rather than by balanced economic growth, business analysts tend to consider at least some African countries and cities as challenging but rewarding places to invest (Economist, 2013).

Overall, this coexistence of opportunities and challenges is likely to have important implications for enterprises emerging to address them. In particular, our discussions suggest two key socioeconomic dimensions that, while not exclusive to sub-Saharan Africa, seem most relevant for the continent: poverty and informality.

\section{Historico-Political Contextual Dimensions}

The historico-political context of sub-Saharan African countries also tends to be more complex than in many parts of the world, even though substantial variations exist across countries. A stream of research has emerged surrounding institutional theory in the context of emerging economies in particular (Julian \& Ofori-Dankwa, 2013; Peng, Sun, Pinkham, \& Chen, 2009; Rivera-Santos et al., 2012), emphasizing the weakness of formal institutions and the resulting importance of understanding the interaction between formal and informal institutions (Zoogah et al., 2015). The Institutional Difference Hypothesis (IDH) discussed by Julian and Ofori-Dankwa (2013) highlights the importance of contextual differences between developed and developing countries. While an emerging stream of work has tested this difference between developed and developing countries, there is little examination of institutional differences across developing countries within a region, suggesting that an extension of IDH is needed as a way to respond to the call by Doh, Lawton, and Rajwani (2012) to consider the non-market environment of businesses in differing institutional contexts.

Among the specificities of the African continent, there is broad agreement in the literature that slav- ery, colonization, and postcolonial relationships have had important implications for sub-Saharan African countries (Hearn, 2007; Herbst, 2000). Studies have repeatedly shown the link between current levels of economic development and the geographic prevalence of slave raids, as well as the impact of these raids on present-day cultural patterns (Nunn \& Wantchekon, 2011; Rodney, 1981; Whatley \& Gillezeau, 2011). The colonial period itself was relatively short in the overall history of the continent, but there is evidence that this period left important traces (Herbst, 2000), with colonial institutions persisting after independence (Acemoglu et al., 2000). For instance, national boundaries were decided by the colonizers, leaving many ethnic groups spread across several countries (Michalopoulos \& Papaioannou, 2012), like the Maasai between Tanzania and Kenya (Coast, 2002). Concurrently, other groups were left to coexist in the same country despite their differences, such as in Nigeria where the heavily centralized Yoruba kingdoms coexist with Igbo communities characterized by institutions without a real central power figure, and with Hausa Islamic urban centers (Njoku, 2006; Ostien, 2007). Recent work by Michalopoulos and Papaioannou (2015) further suggests that differences in these kinds of precolonial ethnic institutions have also had significant implications for later economic performance.

Beyond national boundaries, different colonial powers brought different approaches to colonization and, as a consequence, different forms of formal institutions, often with lasting implications (Herbst, 2000). Acemoglu and co-authors (2000) suggested that former British colonies in the developing world, for example, tend to be more prosperous, have stronger property rights, and exhibit more developed financial markets relative to non-British ex-colonies. Sometimes, patterns of economic dependence also emerged after political independence. The influence of large French businesses and prominent French politicians in many former French African colonies, for instance, was so strong for several decades that the term Françafrique was coined to reflect some French-speaking African countries' political and economic dependence on France (Verschave, 2003). This interference in African institutions by former colonizers, still denounced today as ongoing by prominent African leaders such as Thabo Mbeki (Baldé \& Dayen, 2012), is not restricted to political actors and large businesses. Some authors have argued that African 
nongovernmental organizations (NGOs) are essentially playing the role of agents of Northern institutions in their own countries due to the lack of financial autonomy of these NGOs (Hearn, 2007).

Beyond issues of poor governance often associated with post-independence dynamics (Bräutigam \& Knack, 2004) and the resulting patterns of corruption, with 14 sub-Saharan African countries among the 30 most corrupt countries in the world (Transparency International, 2012), sub-Saharan African countries are characterized by complex institutional layers that seem to be specific to the continent, at least to some extent (Zoogah et al., 2015).

For example, tribal leaders and ethnic dynamics, in particular, still play an important role in many countries, even though it is important to emphasize that differences exist across and within countries, and that recent evolutions seem to point to a strengthening of nation-states through improved governance across the continent (Bräutigam \& Knack, 2004; Herbst, 2000). Nevertheless, the Afrobarometer surveys suggest that tribal leaders still yield an important influence throughout the continent (Robinson, 2009), and that this influence may actually be increasing, at least in some countries. These patterns have important implications for management. Nyambegera (2002, p. 1078) noted that, in Africa, "the[ir] ethnic group is a key source of sociological attachment and serves as an important referent of self-identification." Organizational scholars further suggest that African management practices are influenced by the concept of ubuntu (Mangaliso, 2001; West, 2014), a philosophical thought system of human interdependence, reciprocity, and suppression of self-interest. Communal group and tribal identity is also demonstrated in the Kenyan practice of harambee, whereby financial resources are pooled to undertake communal projects or help friends and family deal with crises or a specific need for funding (Kamoche, 2000).

Thus, two factors emerge within the complex interplay of historico-political characteristics that are particularly pertinent to the African context: ethnic group identity and the influence of colonization. Hence, with the socioeconomic dimensions (which lead to poverty and informality), we have the four contextual dimensions that are particularly pertinent to Africa: acute poverty, informality, colonial history, and ethnic group identity.

\section{THE INFLUENCE OF THE SUB-SAHARAN AFRICAN ENVIRONMENT ON SOCIAL ENTREPRENEURSHIP}

The sub-Saharan African context seems to exhibit particularly interesting characteristics for social entrepreneurship researchers. Social and economic challenges abound, creating needs that can become opportunities for ventures that have at least some social goals. These ventures can range across a spectrum from for-profit commercial business models exploiting niche markets to more socially driven ventures responding to the prevalence of acute needs associated with extreme poverty, institutional voids, vulnerable environmental resources, and marginalized communities. An exploration of the relationship between the specificities of the sub-Saharan African environment and social entrepreneurship is thus likely to provide novel insights.

In this section, we build on the two literature streams (social entrepreneurship and environmental influences) and discuss the expectations concerning the influence of the sub-Saharan African environment on social entrepreneurship. We consider the four contextual dimensions that are particularly pertinent to Africa as discussed above (acute poverty, informality, colonial history, and ethnic group identity) in relation to important dimensions of social entrepreneurship and social enterprise characteristics highlighted in the literature and identified in earlier discussions (the venture's self-perception as a social enterprise and its activities on the ground). The specifications of the empirical study and exploratory hypotheses (including details on sample, data collection, variables, results, and limitations) can be found in the appendix. Below we summarize the key theoretical and empirical insights.

\section{Poverty}

While poverty is a worldwide phenomenon, it is particularly prevalent in sub-Saharan Africa, as explained above. A prevalence of visible poverty, stemming from a combination of high absolute levels of poverty and high inequality, is likely to affect both a venture's self-perception as a social enterprise and its actual activities. As the literature suggests, social entrepreneurship emerges when needs are not fulfilled by the government or the private sector, and when fulfilling these needs can lead to strong positive externalities (Santos, 2012). Both 
dimensions characterize environments of acute poverty, while the eradication of poverty has very important positive externalities for the rest of the economy (World Bank, 2000). Therefore, we can expect higher levels of poverty to affect actual activities by leading to more developed social missions on the ground. These social missions are likely to incorporate a more specific targeting of the poor and, more generally, of marginalized communities in the venture's business model (Seelos \& Mair, 2005), as both their needs and the environments in which they live are significantly different from those of more mainstream customers (RiveraSantos et al., 2012; Subrahmanyan \& GomezArias, 2008).

Social missions in such an environment are also likely to engage the poor in a more inclusive manner, due to the difficulty of fully understanding their needs from the outside (Pless, 2012; Simanis \& Hart, 2008). Beyond the social mission on the ground, an environment characterized by high levels of poverty should also affect the venture's selfperception as a social enterprise, as it is likely to increase the perception of the enterprise's members that they are solving social problems with the venture. In particular, high levels of visible poverty are likely to increase the probability of compassion being transformed into social entrepreneurial ventures (Miller et al., 2012), resulting in a stronger perception of the importance of the social mission by members of the venture. Overall, we can therefore expect that high levels of poverty will lead to a stronger self-perception as a social enterprise and to a choice of activities that emphasize the venture's social mission.

\section{Informality}

Like poverty, informality is a worldwide phenomenon (Godfrey, 2011; ILO, 2012), but it is also particularly prevalent in sub-Saharan Africa due to typically weaker or less efficient formal governments, as mentioned earlier. Although informality is an important dimension of the sub-Saharan African environment, its impact on social entrepreneurship is not straightforward. Both formal and informal businesses can emphasize social missions as much as they can emphasize purely for-profit missions. A local money lender, for instance, may be embedded in the informal economy and target the poor in its business model but still maximize its profits (Collins, Morduch, Rutherford, \& Ruthven, 2009), while a microfinance institution has its roots in the formal economy and typically emphasizes a social mission alongside profitability (Akula, 2008). Similarly, the implications of the prevalence of informality in a venture's environment are not so easy to assess given the link between informality and poverty, which is well established by development economists at the macro and micro levels (De Soto, 2000; Gulyani \& Talukdar, 2010; Günther \& Launov, 2012). Overall, based on current insights, it thus seems difficult to conceptualize the direction of the relationship between the prevalence of informality in sub-Saharan African countries and social entrepreneurship.

\section{Colonial History}

In contrast, we can expect a country's colonial history to influence social entrepreneurship in sub-Saharan Africa as much as it influences other aspects of the economy. While colonization occupied a relatively short time in African countries' history, the impact of the ex-colonizing power is often still felt across a range of dimensions including current levels of economic development (Acemoglu et al., 2000), institutions (Herbst, 2000), and cultural patterns (Nunn \& Wantchekon, 2011; Rodney, 1981; Whatley \& Gillezeau, 2011). As indicated above, scholars have noted that African countries formerly colonized by the British tend to be more prosperous and have more developed formal institutions than African countries formerly colonized by the French, the Belgians, the Germans, or the Portuguese (Acemoglu et al., 2000), suggesting a stronger overall emphasis on, and trust in, economic institutions. This different emphasis seems likely to have implications for social entrepreneurship and, in particular, for how social entrepreneurship is perceived. A stronger emphasis on, and trust in, economic institutions may lead entrepreneurs to view their activities more often as forprofit than as social, reflecting a broader belief in the role of business to solve problems and a more positive experience with economic institutions.

Although the belief in for-profit business is likely to be higher in countries colonized by the British (Acemoglu et al., 2000) and should therefore affect a venture's self-perception as a social enterprise, there is no reason to believe that it should affect the actual activities of the social venture, as these will relate to the needs of the people targeted by the venture, as discussed above, rather than by the belief in for-profit business. We should note that 
this reasoning applies to the effect of British colonization in Africa, and it does not suggest a similar relationship for other former British colonies, such as the United States, India, or New Zealand, as it is based on studies of the effect of colonization on economic development in Africa. Overall, we can thus expect an African country's colonial history to influence the venture's self-perception as a social enterprise but not its actual activities, suggesting a disconnection between self-perception and social mission in this situation.

\section{Ethnic Group Identity}

The sub-Saharan African environment is also characterized by a relatively stronger influence of ethnic groups than other parts of the world (Herbst, 2000; Michalopoulos \& Papaioannou, 2015). Ethnic group identity adds a parallel institutional framework to national institutions, which may be recognized by the state although it is at odds with the state (Posner, 2005). Strong ethnic identities in subSaharan Africa are likely to influence social entrepreneurship as they influence other parts of the economy. In particular, the typically sub-Saharan African ubuntu approach, grounded in a view of the world in which human interdependence and reciprocity are emphasized over individualism (Mangaliso, 2001; West, 2014), may have an impact on social ventures in regions of Africa in which the ethnic or tribal identities are strong.

Regarding self-perception, we can expect social ventures in these regions to associate with a more social than a for-profit-oriented approach, reflecting the less individualistic approach of traditional sub-Saharan Africa's worldviews. Regarding social mission, we can also expect social ventures to choose activities that emphasize the inclusion of communities in decision making, as this is more aligned with the traditional ubuntu and groupbased approach to decision making than with topdown decision structures (Mangaliso, 2001). It is important to note that, although ethnic institutions are typically informal (Herbst, 2000; Rivera-Santos et al., 2012), informality exists both inside and outside of ethnic groups (De Soto, 2000; Godfrey, 2011), explaining why we expect a specific effect of ethnic group identity on social entrepreneurship from informality.

Overall, this reasoning suggests that we can expect the four contextual dimensions to have an influence on both self-perception as a social enterprise and the venture's choice of activities, and thereby provide specifically African insights into our understanding of social entrepreneurship.

\section{AN EMPIRICAL EXPLORATION OF THE INFLUENCE OF THE SUB-SAHARAN AFRICAN ENVIRONMENT}

We carried out an empirical study to explore the hypothesized influence of the environment on social entrepreneurship in 19 sub-Saharan African countries: Angola, Botswana, Burundi, the Democratic Republic of the Congo, Kenya, Lesotho, Madagascar, Malawi, Mauritius, Mozambique, Namibia, Rwanda, the Seychelles, South Africa, Swaziland, Tanzania, Uganda, Zambia, and Zimbabwe. ${ }^{1}$ Given the dearth of information about social enterprises in these countries, and Africa more generally, including a lack of databases about such enterprises in most if not all the countries considered, we undertook an extensive company search and data collection. We collected data through a multi-language survey of social entrepreneurial ventures, which we complemented with additional secondary data from various sources, including the Afrobarometer and the United Nations Development Program. This resulted in sufficient information on 384 social enterprises. The ventures' survey responses were used to test the effect of the four predominantly African contextual dimensions discussed above-poverty, informality, colonization history, and ethnic identity-on the self-perception of the venture as a social enterprise and on its choice of activities reflecting its social mission on the ground. We tested the predicted relationships with a binary logistic regression, reflecting the nature of the variables under study.

Overall, our exploratory results suggest that higher poverty levels and strong ethnic group identities result in a higher probability that the venture will view itself as a social enterprise and that it will choose activities that support its social mission. In contrast, colonization by the British rather than other nations significantly reduces the probability that a venture will view itself as a social enterprise, but has no impact on the actual social mission of the venture on the ground. Informality has no significant effect on either definitional dimension of social entrepreneurship. The results of our exploratory empirical study, therefore, suggest that con-

\footnotetext{
${ }^{1}$ Details about the study's methods and data can be found in the appendix.
} 
textual dimensions that are especially prevalent in the sub-Saharan African environment influence social entrepreneurship. These findings highlight the insights that African data can provide to our understanding of the importance of better incorporating contextual dimensions in social entrepreneurship research. They also suggest a need to incorporate both self-perception and the choice of activities made by social ventures on the ground to develop a complete definition of social entrepreneurship, as both dimensions are empirically distinct.

\section{CONCLUSIONS AND IMPLICATIONS}

The goal of this paper was to contribute to the debate around social entrepreneurship by highlighting the importance of incorporating contextual influences, thus responding to calls for a better understanding of the relationship between social enterprises and their environments (Bacq \& Janssen, 2011; Mair \& Martí, 2006) and helping to clarify definitional issues in the field. We did so by exploring the influence of contextual dimensions that are particularly prominent in sub-Saharan Africa, thereby underscoring the insights that can come from using African data to inform broader academic discussions. We developed predictions regarding the impact of poverty, informality, colonization history, and ethnic identity on the venture's self-perception as a social enterprise and on its choices of activities reflecting its social mission. Using a unique dataset of 384 social enterprises from 19 sub-Saharan African countries, we conducted exploratory tests of the predicted relationships (detailed more expansively in the appendix to this paper). Both our reasoning and our results suggest that ethnic group identity and high poverty levels affect both self-perception and the choice of activities to reflect a social mission. In contrast, colonial history influences self-perception as a social enterprise but has no effect on the choice of activities on the ground. Informality has no significant effect on either dimension.

We believe that this study, albeit exploratory in nature, has several implications for social entrepreneurship research and opens interesting avenues for future studies. First, we underscore the importance of contextual dimensions not only for the self-perception of social enterprises but also for their actual activities on the ground. In so doing, we take a first step in responding to calls for a better understanding of the relationship between social enterprises and their environment (Bacq \& Janssen,
2011; Mair \& Martí, 2006). Incorporating the environment in social entrepreneurship research can help us better understand why different types of social enterprises seem to exist around the world and, in the process, maybe help settle ongoing debates about what social entrepreneurship is (Choi \& Majumdar, 2014; Lehner \& Kansikas, 2013). We take a first step in this direction, as our findings suggest that African social enterprises may not only be different from the implicit view of social enterprises prevalent in the literature, but may also vary significantly across African contexts. More research contrasting social entrepreneurship models in different parts of the world is likely to provide important insights.

Second, our reasoning and our results also highlight the differences that may exist between a venture's self-perception as a social enterprise and its activities on the ground. This study suggests that these dimensions are not only conceptually different, but that they are also empirically different constructs with different determinants, at least in subSaharan African contexts. Recognizing that social entrepreneurs may not self-identify as social entrepreneurs in some contexts, despite their having all the characteristics of social entrepreneurs in the literature, has important implications for data collection strategies, as it has become relatively common for researchers to rely on self-perception to identify social entrepreneurs (Lyon et al., 2010; Mair et al., 2012; Meyskens et al., 2010). Our data on social enterprises that have the main characteristic recognized in the literature (i.e., the combination of profit and social goals) shows that a large proportion of these social enterprises do not see themselves as such, and would not have been included in a sample of purely self-identifying social entrepreneurs. An exploration of what may lead to this disconnection between self-perception and social mission in the actual activities of the venture across different environments is thus also likely to provide important insights. We believe that this exploration is particularly important, as it has implications for the very definition of social entrepreneurship. Although our goal is not to provide a new definition of the phenomenon, our reasoning and our findings suggest that scholars need to incorporate both self-perception (Lyon et al., 2010; Mair et al., 2012; Meyskens et al., 2010) and the choice of activities on the ground (Doherty et al., 2014; Santos, 2012) as two distinct dimensions of the definition of social entrepreneurship instead of focusing on one or the other. 
Third, our exploratory analysis of sub-Saharan African social enterprises not only helps to expand our knowledge of sub-Saharan Africa but also highlights the insights that African data can bring to the social entrepreneurship literature, especially for phenomena that are particularly prevalent in the African context, such as poverty or informality (Bruton, 2010; Bruton, Ireland, \& Ketchen, 2012). Perhaps reflecting the challenges associated with data collection in Africa (Kolk \& Lenfant, in press), very few studies use multi-country African survey data in the broader management literature. Our approach may be insightful for other scholars pursuing empirical research in such nontraditional contexts. We adapted the data collection strategies to a certain extent, to reflect the characteristics of such environments, as recommended by several scholars (Kriauciunas, Parmigiani, \& Rivera-Santos, 2011) (see the appendix for a discussion of details and reflections on limitations). This empirical study, therefore, helps reinforce the argument that important insights can be gathered from African data and generates research that contributes to defining African contexts and identities (Zoogah, 2008; Zoogah \& Nkomo, 2013). Our exploratory results, for instance, underscore the importance of ethnic identification and traditional worldviews for social enterprises. Even though ethnic identification may be more prevalent in Africa than in other parts of the world, and even though worldviews such as ubuntu (Mangaliso, 2001; West, 2014) may be specifically African, they can help inform future studies on the impact of cultural or ethnic identification on management practices around the world, and thus enrich our understanding of the impact of institutional differences on management (Peng et al., 2009).

Beyond the insights that African data can provide to management studies in general, this research also illustrates the need to better understand differences across developing country contexts, in an extension of Julian and Ofori-Dankwa's (2013) Institutional Difference Hypothesis. This particular study focuses on contextual dimensions that are prevalent across sub-Saharan Africa, but exploring country-specific or even community-specific dimensions is also likely to provide important insights. Ethnic identification, for instance, can be expected to have different implications for business depending on whether the ethnic institutions are acephalous (decentralized) or monarchical (centralized) (Cheater, 2003; Rivera-Santos et al., 2012). This suggests that more fine-grained analy- ses at the country or even community level can provide additional, and complementary, insights to our sub-Saharan Africa-wide study.

This study of the influence of predominantly African contextual characteristics on social entrepreneurship thus opens up several avenues for future research while illustrating the insights that African data can provide to management studies. Through this exploratory research, we contend that African data, although difficult to collect, may help relax implicit contextual assumptions in our understanding of management, and we hope that this study will encourage researchers to better integrate African insights into management theories.

\section{REFERENCES}

Acemoglu, D., Johnson, S., \& Robinson, J. A. (2000). The colonial origins of comparative development: An empirical investigation. Cambridge, MA: National Bureau of Economic Research.

Akula, V. (2008). Business basics at the base of the pyramid. Harvard Business Review, 86(6), 53-57.

Alkire, S., Conconi, A., \& Roche, J. M. (2012). Multidimensional Poverty Index 2012: Brief methodological note and results. Oxford, UK: University of Oxford, Department of International Development, Oxford Poverty and Human Development Initiative.

Bacq, S., \& Janssen, F. (2011). The multiple faces of social entrepreneurship: A review of definitional issues based on geographical and thematic criteria. Entrepreneurship and Regional Development, 23(5-6), 373-403.

Baldé, A., \& Dayen, C. (2012). Thabo Mbeki: “The relationship between Africa and its ex-colonizers is illegal!” Retrieved May 2013 from http://www.afriknews.com/article19444.html

Barkemeyer, R., Figge, F., \& Holt, D. (2013). Sustainability-related media coverage and socioeconomic development: A regional and North-South perspective. Environment and Planning C: Government and Policy, 31(4), 716-740.

Bräutigam, D. A., \& Knack, S. (2004). Foreign aid, institutions, and governance in sub-Saharan Africa. Economic Development and Cultural Change, 52(2), 255-285.

Bruton, G. D. (2010). Business and the world's poorest billion: The need for an expanded examination by management scholars. Academy of Management Perspectives, 24(3), 6-10.

Bruton, G. D., Ireland, R. D., \& Ketchen, D. J. (2012). Toward a research agenda on the informal economy. Academy of Management Perspectives, 26(3), 1-11. 
Cheater, A. P. (2003). Social anthropology. New York: Routledge/Taylor \& Francis.

Cho, A. H. (2006). Politics, values and social entrepreneurship: A critical appraisal. In J. Mair, J. Robinson, \& K. Hockerts (Eds.), Social entrepreneurship (pp. 34-56). Basingstoke, UK: Palgrave Macmillan.

Choi, N., \& Majumdar, S. (2014). Social entrepreneurship as an essentially contested concept: Opening a new avenue for systematic future research. Journal of Business Venturing, 29(3), 363-376.

Coast, E. (2002). Maasai socioeconomic conditions: A cross-border comparison. Human Ecology, 30(1), 79-105.

Collins, D., Morduch, J., Rutherford, S., \& Ruthven, O. (2009). Portfolios of the poor: How the world's poor live on $\$ 2$ a day. Princeton, NJ: Princeton University Press.

Dacin, M. T., Dacin, P. A., \& Tracey, P. (2011). Social entrepreneurship: A critique and future directions. Organization Science, 22(5), 1203-1213.

Dacin, P. A., Dacin, M. T., \& Matear, M. (2010). Social entrepreneurship: Why we don't need a new theory and how we move forward from here. Academy of Management Perspectives, 24(3), 36-56.

Das, P., \& Samarasekera, U. (2012). The story of GBD 2010: A "super-human" effort. Lancet, 380(9859), 2067-2070.

Defourny, J., \& Nyssens, M. (2008). Social enterprise in Europe: Recent trends and developments. Social Enterprise Journal, 4(3), 202-228.

De Soto, H. (2000). The mystery of capital: Why capitalism triumphs in the West and fails everywhere else. New York: Basic Books.

Doh, J. P., Lawton, T. C., \& Rajwani, T. (2012). Advancing nonmarket strategy research: Institutional perspectives in a changing world. Academy of Management Perspectives, 26(3), 22-39.

Doherty, B., Haugh, H., \& Lyon, F. (2014). Social enterprises as hybrid organizations: A review and research agenda. International Journal of Management Reviews, 16(4), 417-436.

Economist. (2011, December 3). The hopeful continent: Africa rising. Retrieved from http://www.economist. com/node/21541015

Economist. (2013, April 6). Investing in Africa: The hottest frontier. Retrieved from http://www.economist.com/ news/finance-and-economics/21575769-strategiesputting-money-work-fast-growing-continent-hottest

Egri, C. P., \& Ralston, D. A. (2008). Corporate responsibility: A review of international management research from 1998 to 2007. Journal of International Management, 14(4), 319-339.
Financial Times. (2013, May 6). Value creation, a sustainable firm or venture philanthropy? Financial Times, p. 9.

Godfrey, P. C. (2011). Toward a theory of the informal economy. Academy of Management Annals, 5(1), 231-277.

Gulyani, S., \& Talukdar, D. (2010). Inside informality: The links between poverty, microenterprises, and living conditions in Nairobi's slums. World Development, 38(12), 1710-1726.

Günther, I., \& Launov, A. (2012). Informal employment in developing countries: Opportunity or last resort? Journal of Development Economics, 97(1), 88-98.

Hearn, J. (2007). African NGOs: The new compradors? Development and Change, 38(6), 1095-1110.

Herbst, J. (2000). States and power in Africa: Comparative lessons in authority and control. Princeton, NJ: Princeton University Press.

ILO. (2012). Statistical update on employment in the informal economy. Geneva, Switzerland: International Labor Organization.

International Monetary Fund. (2013). World economic outlook database. Retrieved from http://www.imf. org/external/pubs/ft/weo/2013/01/weodata/index. aspx

Julian, S. D., \& Ofori-Dankwa, J. C. (2013). Financial resource availability and corporate social responsibility expenditures in a sub-Saharan economy: The Institutional Difference Hypothesis. Strategic Management Journal, 34(11), 1314-1330.

Kamoche, K. N. (2000). Sociological paradigms and human resources: An African context. Aldershot, UK: Ashgate Publishing Ltd.

Kerlin, J. A. (2006). Social enterprise in the United States and Europe: Understanding and learning from the differences. Voluntas: International Journal of Voluntary and Nonprofit Organizations, 17(3), 246262.

Kolk, A., \& Lenfant, F. (in press). Partnerships for peace and development in fragile states: Identifying missing links. Academy of Management Perspectives.

Kolk, A., Rivera-Santos, M., \& Rufín, C. (2014). Reviewing a decade of research on the "base/bottom of the pyramid" (BOP) concept. Business and Society, 53(3), 338-377.

Kolk, A., \& Van Tulder, R. (2010). International business, corporate social responsibility, and sustainable development. International Business Review, 19(2), $119-125$

Kotkin, J., \& Cox, W. (2013, April 8). The world's fastestgrowing megacities. Forbes. Available at http:// 
www.forbes.com/sites/joelkotkin/2013/04/08/theworlds-fastest-growing-megacities/

Kriauciunas, A., Parmigiani, A., \& Rivera-Santos, M. (2011). Leaving our comfort zone: Integrating established practices with unique adaptations to conduct survey-based strategy research in non-traditional contexts. Strategic Management Journal, 32(9), 9941010.

Leadbeater, C. (2007). Social enterprise and social innovation: Strategies for the next ten years. London: Cabinet Office of the Third Sector.

Lehner, O. M., \& Kansikas, J. (2013). Pre-paradigmatic status of social entrepreneurship research: A systematic literature review. Journal of Social Entrepreneurship, 4(2), 198-219.

Lyon, F., Teasdale, S., \& Baldock, R. (2010). Approaches to measuring the scale of the social enterprise sector in the UK (Working Paper). Birmingham, UK: University of Birmingham.

Mair, J., Battilana, J., \& Cardenas, J. (2012). Organizing for society: A typology of social entrepreneuring models. Journal of Business Ethics, 111(3), 353-373.

Mair, J., \& Martí, I. (2006). Social entrepreneurship research: A source of explanation, prediction, and delight. Journal of World Business, 41(1), 36-44.

Mangaliso, M. P. (2001). Building competitive advantage from ubuntu: Management lessons from South Africa. Academy of Management Executive, 15(3), 2333.

McGahan, A. M. (2012). Challenges of the informal economy for the field of management. Academy of Management Perspectives, 26(3), 12-21.

Meyskens, M., Robb-Post, C., Stamp, J. A., Carsrud, A. L., \& Reynolds, P. D. (2010). Social ventures from a resource-based perspective: An exploratory study assessing global Ashoka fellows. Entrepreneurship Theory and Practice, 34(4), 661-680.

Michalopoulos, S., \& Papaioannou, E. (2012). National institutions and African development: Evidence from partitioned ethnicities. Cambridge, MA: National Bureau of Economic Research.

Michalopoulos, S., \& Papaioannou, E. (2015). On the ethnic origins of African development: Traditional chiefs and precolonial political centralization. Academy of Management Perspectives, this issue.

Miller, T. L., Grimes, M. G., McMullen, J. S., \& Vogus, T. J. (2012). Venturing for others with heart and head: How compassion encourages social entrepreneurship. Academy of Management Review, 37(4), $616-640$.

Montgomery, A. W., Dacin, P. A., \& Dacin, M. T. (2012). Collective social entrepreneurship: Collaboratively shaping social good. Journal of Business Ethics, 111(3), 375-388.

Njoku, R. C. (2006). African cultural values: Igbo political leadership in colonial Nigeria, 1900-1966. London, UK: Routledge.

Nunn, N., \& Wantchekon, L. (2011). The slave trade and the origins of mistrust in Africa. American Economic Review, 101(7), 3221-3252.

Nyambegera, S. M. (2002). Ethnicity and human resource management practice in sub-Saharan Africa: The relevance of the managing diversity discourse. International Journal of Human Resource Management, 13(7), 1077-1090.

Ostien, P. (2007). Sharia implementation in northern Nigeria 1999-2006: The Sharia penal and criminal procedure codes. Ibadan, Nigeria: Spectrum Books.

Parkinson, C., \& Howorth, C. (2008). The language of social entrepreneurs. Entrepreneurship and Regional Development, 20(3), 285-309.

Partzsch, L., \& Ziegler, R. (2011). Social entrepreneurs as change agents: A case study on power and authority in the water sector. International Environmental Agreements: Politics, Law and Economics, 11(1), 6383.

Peattie, K., \& Morley, A. (2008). Eight paradoxes of the social enterprise research agenda. Social Enterprise Journal, 4(2), 91-107.

Peng, M. W., Sun, S. L., Pinkham, B., \& Chen, H. (2009). The institution-based view as a third leg for a strategy tripod. Academy of Management Perspectives, 23(3), 63-81.

Pless, N. M. (2012). Social entrepreneurship in theory and practice-An introduction. Journal of Business Ethics, 111(3), 317-320.

Posner, D. N. (2005). Institutions and ethnic politics in Africa. Cambridge, UK: Cambridge University Press.

Rivera-Santos, M., Rufín, C., \& Kolk, A. (2012). Bridging the institutional divide: Partnerships in subsistence markets. Journal of Business Research, 65(12), 17211727.

Robinson, A. L. (2009). National versus ethnic identity in Africa: State, group, and individual level correlates of national identification (Working Paper No. 112). Afrobarometer.

Rodney, W. (1981). How Europe underdeveloped Africa. Washington, DC: Howard University Press.

Santos, F. M. (2012). A positive theory of social entrepreneurship. Journal of Business Ethics, 111(3), 335351.

Seelos, C., \& Mair, J. (2005). Social entrepreneurship: Creating new business models to serve the poor. Business Horizons, 48(3), 241-246. 
Simanis, E., \& Hart, S. L. (2008). The base of the pyramid protocol: Toward next generation BoP strategy (version 2.0). Ithaca, NY: Cornell University, Center for Sustainable Global Enterprise.

Stigand, C. H. (1915). A grammar of dialectic changes in the Kiswahili language. Cambridge, UK: University Press.

Subrahmanyan, S., \& Gomez-Arias, J. T. (2008). Integrated approach to understanding consumer behavior at bottom of pyramid. Journal of Consumer Marketing, 25(7), 402-412.

Trading Economics. (2013). DP growth in sub-Saharan African. Retrieved from http://www.tradingeconomics.com/ sub-saharan-africa/gdp-growth-annual-percentwb-data.html

Transparency International. (2012). Corruption perceptions index 2012. Berlin: Author. Retrieved from http://www.transparency.org/cpi2012/results

UNDP. (2009). Human development report. New York: United Nations Development Programme.

UNDP. (2010). Human poverty index. New York: United Nations Development Programme. Retrieved from http://hdr.undp.org/en/statistics/understanding/ indices/hpi/

Verschave, F.-X. (2003). Françafrique: Le plus long scandale de la République. Paris: Stock.

Vision of Humanity. (2012). Global peace index. New York: Institute for Economics and Peace. Retrieved from http://www.visionofhumanity.org/gpi-data/\#/ 2010/GINI

West, A. (2014). Ubuntu and business ethics: Problems, perspectives and prospects. Journal of Business Ethics, 121(1), 47-61.

Whatley, W. C., \& Gillezeau, R. (2011). The fundamental impact of the slave trade on African economies. In P. Rhode, J. Rosenbloom, \& D. Weiman (Eds.), Economic evolution and revolution in historical time (pp. 86-110). Stanford, CA: Stanford University Press.

World Bank. (2000). World development report 2000/ 2001: Attacking poverty. Oxford, UK: Oxford University Press.

World Bank. (2010). Poverty headcount ratio at $\$ 2$ a day (\% of population). Washington, DC: Author. Retrieved from http://data.worldbank.org/indicator/SI. POV.2DAY

World Bank. (2012). Doing business economy rankings. Washington, DC: Author. Retrieved from http:// www.doingbusiness.org/rankings

World Bank. (2013). GDP growth (annual \%) data. Washington, DC: Author. Retrieved from http://data. worldbank.org/indicator/NY.GDP.MKTP.KD.ZG
World Bank. (2014). GINI index. Washington, DC: Author. Retrieved from http://data.worldbank.org/ indicator/SI.POV.GINI/

Zahra, S. A., Gedajlovic, E., Neubaum, D. O., \& Shulman, J. M. (2009). A typology of social entrepreneurs: Motives, search processes and ethical challenges. Journal of Business Venturing, 24(5), 519-532.

Zoogah, D. B. (2008). African business research: A review of studies published in the Journal of African Business and a framework for enhancing future studies. Journal of African Business, 9(1), 219-255.

Zoogah, D. B., \& Nkomo, S. (2013). Management research in Africa: Past, present and future possibilities. In T. Lituchy, B. Punnett, \& B. Puplampu (Eds.), Management in Africa: Macro and micro perspectives (pp. 9-31). New York: Routledge.

Zoogah, D. B., Peng, M. W., \& Woldu, H. (2015). Institutions, resources, and organizational effectiveness in Africa. Academy of Management Perspectives, this issue.

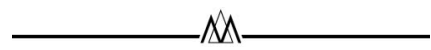

Diane Holt (dholt@essex.ac.uk) is a senior lecturer in management at Essex Business School at the University of Essex, UK. Her research interests focus on business models associated with sustainable development and poverty alleviation, especially within sub-Saharan Africa, as well as issues associated with sustainability topics more broadly.

Ans Kolk (akolk@uva.nl) is a full professor at the University of Amsterdam Business School in the Netherlands. Her research focuses on international business in relation to societal topics, particularly poverty and development; partnerships; voluntary standard-setting, disclosure, and accountability; and climate change and energy.

David Littlewood (d.c.littlewood@reading.ac.uk) is a lecturer at the Henley Business School at the University of Reading, UK. His research interests include corporate social responsibility, sustainability, corporate reputation management, and social entrepreneurship and innovation, geographically focused on the developing world and particularly sub-Saharan Africa.

Miguel Rivera-Santos (mrivera@babson.edu) is an associate professor of strategy and international business at Babson College in Wellesley, Massachusetts. His research examines the implications, for organizations and communities, of bridging the gap between different institutional contexts, especially in the context of subsistence markets. 


\section{APPENDIX}

In this appendix, we provide more detail on the empirical study conducted to test the relationships predicted in the paper. Our reasoning suggested that we could expect four contextual dimensions to have an influence on social entrepreneurship, and thereby provide specifically African insights into our understanding of social entrepreneurship. This leads to four exploratory hypotheses on the effect of sub-Saharan African contexts on social entrepreneurship:

H1: Higher levels of poverty will increase the probability of a venture's self-perception as a social enterprise and an emphasis on its social mission in its activities, ceteris paribus.

H2: Higher levels of informality should not directly influence the probability of a venture's self-perception as a social enterprise and an emphasis on its social mission in its activities, ceteris paribus.

H3: Having a British colonial history will decrease the probability of a venture's self-perception as a social enterprise and an emphasis on its social mission in its activities, ceteris paribus.

H4: Higher levels of ethnic group identification will increase the probability of a venture's self-perception as a social enterprise and an emphasis on its social mission in its activities, ceteris paribus.

The next sections present the sample, data collection, variables and measures, the empirical tests and results, and discussion of the limitations.

\section{Sample Selection and Data Collection}

To test the exploratory hypotheses developed in the paper, we built a sample of social enterprises active in Southern and Eastern Africa. The data for this study were collected as part of the Trickle Out Africa research project, a research project examining social enterprises and environmental enterprises (hereafter labeled as social enterprises) in Eastern and Southern Africa and their potential role in sustainable development and poverty alleviation. This is an ongoing project founded and managed by Holt and Littlewood, initiated in 2011. In the first stage of this project, relevant enterprises, support agencies, NGOs, and other nonprofit entities were identified through an exhaustive Internet search undertaken by the research team. From this initial directory of examples an online survey was conducted with social enterprises across the 19 countries in the Southern African Development Community (SADC) and the East African Community (EAC). As a framework guiding this search, we identified several social enterprise characteristics, drawing on definitions and understandings in the antecedent literature and among practitioner organizations. These included the presence of a social, environmental, or broader ethical mission; income generation through trad- ing activity; non-profit-maximizing approaches to business; participatory decision-making and governance; innovation in addressing a social need; and profits or surpluses reinvested in the business or for social purposes. We looked for evidence of one, some, or all of these traits in publicly available information (in this case, the Internet) about the organizations. The specific strategy we adopted in online data searching involved keyword searches for particular countries or sectors (e.g., "green business South Africa”), and we used online databases and alternative business directories such as regional organic associations or membership information for social enterprise networks such as the African Social Entrepreneurs Network (ASEN). Finally, we accessed available resources and data from national governments and international institutions.

Once a potential social enterprise from one of the 19 sub-Saharan countries was identified, a record was made of its contact details (e.g., e-mail accounts, telephone numbers, or postal addresses) and areas of activity. In total, we found information for more than 3,900 potential social enterprises, detailed in full in the enterprise directory hosted on the Trickle Out Africa Web site. Social networks and press releases were also used to facilitate dissemination about the project aims, and included links to the self-registration process for the online directory. The overall approach adopted in identifying potential social enterprises reflects the dearth of information about these kinds of enterprises in Africa, and the fact that there are few if any databases of such enterprises for most if not all the countries considered. Social enterprises also exist in a myriad of country- and context-specific legal forms, which would problematize any attempt to approach all organizations with a particular legal status (e.g., nonprofit/not-for-profit), even if up-to-date information on these types of organizations existed, was accessible, and included contact details.

We then contacted the enterprises in our dataset to verify their details in the free enterprise directory, with a request to also participate in the research. Organizations were contacted principally through e-mail with a link to the registration/verification process for the directory with an embedded link to an online questionnaire, but also in some instances were initially contacted by telephone. A project overview and introductory document informed participants about the nature of the research, explained their rights in participation, and outlined the benefits of participation, including entry into a prize drawing and more detail on their inclusion in the Trickle Out Directory of social enterprises hosted on the project Web site. A number of additional filters were applied within the registration/verification process, including that enterprises had to be operating in at least one of 19 countries comprising the member states of the SADC and EAC, Angola, Botswana, Burundi, the Democratic Republic of the Congo, Kenya, Lesotho, Madagascar, Malawi, Mauritius, Mozambique, Namibia, Rwanda, the Sey- 
chelles, South Africa, Swaziland, Tanzania, Uganda, Zambia, and Zimbabwe. In the initial registration participants were also asked to verify that they engaged in some form of trading activity and whether they had a social and/or environmental mission, thereby reflecting the general agreement in the literature that social enterprises are characterized by a combination of economic and social goals. Enterprises that did not meet these criteria could not complete the questionnaire. The unit of analysis in this study is therefore the social enterprise rather than its founder or leader, and the questionnaire was completed by top managers or owners to ensure a broad and comprehensive knowledge of their venture's activities and organization.

The themes addressed in the survey were relatively broad, reflecting our aim of addressing some of the gaps in knowledge about these kinds of enterprises in Africa. They included, among others, questions on funding regimes, business models and structures, venture start-up, customers, decision making, and profit distribution. The questionnaire was piloted using a sample of respondents. The questions were mostly categorical or scale measures, with some free text sections including a section where enterprises described their business and market to give us a more nuanced view of their operations. English, French, Portuguese, Kiswahili, and Afrikaans versions of the questionnaire were created to encourage participation; these are all official national languages in at least two of the 19 countries examined, and are major languages spoken across Eastern and Southern Africa. In total, we collected 400 responses; this number was reduced to 384 after we removed questionnaires that did not allow enough information to classify the nature of the enterprise or did not include the name of the organization or business (summarized in Table 1).

In addition to the data collected through the survey, each top manager or owner responding to the questionnaire verified the name of the organization and the contact details, and provided a free text description for the publicly available directory. This text was examined for each enterprise to determine the precise nature of their activity. Data provided on self-perception as a nonprofit, cooperative, social enterprise, and/or environmental (green) enterprise, and on funding regimes, alongside the free text, was used to code the type of enterprises. Data were confirmed, where possible, through the Web address details and secondary data available from the original online scanning exercise, including Web sites, newspaper reports, and blog posts.

Complementing the data collected through the survey, we gathered country-wide economic and institutional data from a variety of external sources. These sources included the Afrobarometer, the World Bank, UNECA, Transparency International, and the United Nations Development Program (summarized in Table 2).
TABLE 1

An Overview of Respondents

\begin{tabular}{lrlr}
\hline \multicolumn{2}{c}{ Distribution by country } & \multicolumn{2}{c}{ Distribution by category } \\
\hline & & Distribution by age & \\
Angola & 3 & 3 years or less & 62 \\
Botswana & 10 & 4-10 years & 159 \\
Burundi & 1 & 10 years or more & 106 \\
DRC & 4 & Distribution by self-perception & 168 \\
Kenya & 104 & For-profit enterprise & 139 \\
Lesotho & 9 & Social enterprise & \\
Madagascar & 10 & Distribution by size & 94 \\
Malawi & 18 & Small (2-50) & 123 \\
Mauritius & 4 & Medium (51-500) & 18 \\
Mozambique & 7 & Large (over 500) & 204 \\
Namibia & 5 & Distribution by activity & \\
Rwanda & 9 & Sales-focused activity & \\
Seychelles & 1 & Knowledge transfer-focused activity & 180 \\
South Africa & 113 & & \\
Swaziland & 3 & & \\
Tanzania & 23 & & \\
Uganda & 23 & & \\
Zambia & 13 & & \\
Zimbabwe & 15 & & \\
Worldwide & 9 & & \\
\hline
\end{tabular}

Note: Different total numbers in each category reflect respondents in multiple categories and missing data for some variables.

\section{Empirical Strategy}

The exploratory hypotheses suggest that an African country's poverty levels, informality, colonial history, and strength of ethnic identities are likely to influence its social ventures' self-perception as social enterprises and their choice of activities. We measure these different concepts through variables constructed from questionnaire items and from external sources, thereby reducing potential issues related to single-method bias. Table 3 describes each variable in detail.

We constructed three dependent dichotomous variables to capture self-perception as a social enterprise and the social mission, based on questionnaire data collected through the survey: self-perception as a social enterprise and choice of activities. One variable captures self-perception as a social enterprise, but we included two dimensions for the choice of activities: the specific targeting of the poor and the choice to include the community in decision making, thereby incorporating both the business model and the organizational processes in the measure of social mission. Through these three dependent variables, we therefore capture not only the self-perception of being a social enterprise but also the social mission of the enterprise, two typical proxies for the definition of social entrepreneurship in the literature (Doherty et al., 2014; Lyon et al., 2010; Mair et al., 2012; Meyskens et al., 2010; Santos, 2012). Because our reasoning suggests that we should expect different determinants of self-perception and of social mission, as seen through the actual activities of the venture in the sub-Saharan African context, it is important to disentangle these two dimensions into three different constructs. 
TABLE 2

An Overview of National Environments

\begin{tabular}{|c|c|c|c|c|c|c|c|}
\hline Country & HDI rank & $\begin{array}{l}\text { Ease of doing } \\
\text { business } \\
\text { rank }\end{array}$ & $\begin{array}{l}\text { World Bank income } \\
\text { status }\end{array}$ & GDP/capita & Corruption rank & $\begin{array}{c}\text { Colonial power } \\
\text { (1914) }\end{array}$ & Independence \\
\hline Angola & Low & 172 & Upper middle & 5,485 & very high & Portugal & 1975 \\
\hline Botswana & Medium & 59 & Upper middle & 7,191 & low & UK & 1966 \\
\hline Burundi & Low & 159 & Low income & 251 & very high & Germany & 1962 \\
\hline DRC & Low & 181 & Low income & 272 & very high & Belgium & 1960 \\
\hline Kenya & Low & 121 & Low income & 862 & very high & UK & 1963 \\
\hline Lesotho & Low & 136 & Lower middle & 1,193 & low/med. & UK & 1966 \\
\hline Madagascar & Low & 142 & Low income & 447 & med./high & France & 1960 \\
\hline Malawi & Low & 157 & Low income & 268 & low/med. & UK & 1964 \\
\hline Mauritius & High & 19 & Upper middle & 8,124 & low & France & 1968 \\
\hline Mozambique & Low & 146 & Low income & 579 & med./high & Portugal & 1975 \\
\hline Namibia & Medium & 87 & Upper middle & 5,668 & very high & Germany & 1990 \\
\hline Rwanda & Low & 52 & Low income & 620 & very high & Germany & 1962 \\
\hline Seychelles & High & 74 & Upper middle & 11,758 & low/med. & UK & 1976 \\
\hline South Africa & Medium & 39 & Upper middle & 7,508 & low/med. & UK & 1910 \\
\hline Swaziland & Medium & 123 & Lower middle & 3,044 & low/med. & UK & 1968 \\
\hline Tanzania & Low & 134 & Low income & 609 & med./high & Germany & 1961 \\
\hline Uganda & Low & 120 & Low income & 547 & med./high & Germany & 1962 \\
\hline Zambia & Low & 94 & Lower middle & 1469 & low/med. & UK & 1964 \\
\hline Zimbabwe & Low & 172 & Low income & 788 & very high & UK & 1980 \\
\hline
\end{tabular}

Note: Sources from the World Bank, United Nations, Ease of Doing Business Reports, and Transparency International.

We constructed four independent variables to capture the contextual dimensions in sub-Saharan Africa through secondary sources. The measure for the level of poverty was imported from the multidimensional Human Poverty Index (HPI) calculations of the United Nations Development Program (UNDP, 2010). The UNDP replaced the HPI in 2010 with a new measure of poverty, the Multidimensional Poverty Index (Alkire, Conconi, \& Roche, 2012). The new index, however, is available for only a subset of African countries, leading us to opt for the older HPI as our measure of poverty.

Measuring informality is a particularly arduous task, due to the inherently hidden nature of the concept being measured (Godfrey, 2011). Existing measures of informality through employment (e.g., ILO, 2012) could not be used due to a lack of data for many African countries, so we opted for a novel approach. We built a scale using nine items from various Afrobarometer surveys that are all related to the respondent's opinion around the avoidance of taxes, aiming to capture a country's general feeling about taxation and, as a consequence, about the formal economy. Given a high Cronbach's alpha (0.78) for the scale, we could extract the main underlying factor, which we used as a measure of informality in our models.

The nationality of the country's ex-colonizer was coded as a dichotomous variable, corresponding to whether the region was under British rule on one hand, or under German, Belgian, Portuguese, or French rule on the other, in 1914. While the latter countries varied in their colonial approaches, the literature suggests that the British Empire, in particular through its focus on indirect rule, stands apart from the others (Herbst, 2000), thereby justifying the creation of a dichotomous variable. Finally, we used data from the Afrobarometer surveys to measure the strength of ethnic group identities in a given country (Robinson, 2009).

We used items from our survey to control for the size of the venture, the age of the venture, and the venture activity, which we coded as a dichotomous variable reflecting the venture's focus on selling a product or service versus transferring knowledge, training, or consulting, as these represent two very different types of social business models.

Given the binomial nature of the dependent variables, we opted for a binary logistic regression, using the PROC LOGISTIC procedure in SAS 9.3, to test our exploratory hypotheses. Table 4 presents the descriptive statistics and correlations for our variables. From the correlation table, it is interesting to note that, although our three dependent variables are correlated, the correlation levels $\left(0.53^{* *}, 0.30^{* * *}\right.$, and 0.19 respectively) suggest the existence of three different constructs. These results highlight the need for researchers to be careful when using self-identification as a proxy for social entrepreneurship, as significant differences seem to exist between perception and reality in this case.

\section{Results}

The results of the models are presented in Table 5 . Model 1 predicts the probability of the venture's selfperception as a social enterprise. The fit indices suggest that the model fits the data well, and the model supports the predictions of our exploratory hypotheses. A country's higher poverty level significantly increases the probability that social ventures will view themselves as 
TABLE 3

Variables and Measures

\begin{tabular}{|c|c|c|}
\hline Variable & Type & Construction \\
\hline Self-perception as a social enterprise & Dichotomous & $\begin{array}{l}\text { Survey item: "We are a social enterprise that is part funded by the monies } \\
\text { we generate from our goods and services, or from donor funds." ( } 0= \\
\text { not a social enterprise } 1=\text { social enterprise })\end{array}$ \\
\hline Specific targeting of the poor & Dichotomous & $\begin{array}{l}\text { Survey item: "Describe your customers." (Responses coded as } 0=\text { no } \\
\text { specific targeting of the poor and disenfranchised } / 1=\text { specific targeting } \\
\text { of the poor and disenfranchised) }\end{array}$ \\
\hline $\begin{array}{l}\text { Inclusion of the community in important } \\
\text { decisions }\end{array}$ & Dichotomous & $\begin{array}{l}\text { Survey item: "Who makes the most important business decisions or those } \\
\text { for the future for this organisation?" (Responses coded } 0=\text { internal/ } 1= \\
\text { inclusion of community and stakeholders) }\end{array}$ \\
\hline Human Poverty Index & Continuous & Multidimensional index by the United Nations Development Program \\
\hline British colonization & Dichotomous & $\begin{array}{l}\text { Coding of colonial situation in } 1914 \text { ( } 0=\text { German, Belgian, Portuguese, or } \\
\text { French rule } / 1=\text { British rule) }\end{array}$ \\
\hline Ethnic identity & Continuous & $\begin{array}{l}\text { Afrobarometer survey item: "Let us suppose that you had to choose } \\
\text { between being a [Ghanaian] and being a [R's Ethnic Group]. Which of } \\
\text { the following best expresses your feelings?" }\end{array}$ \\
\hline Informality & Continuous & $\begin{array}{l}\text { Factor extracted from the following Afrobarometer survey items } \\
\text { (Cronbach's alpha = 0.78): } \\
\text { - "In your opinion, how often, in this country: Do people avoid paying } \\
\text { the taxes that they owe the government?" } \\
\text {-"Here is a list of actions that people sometimes take as citizens. For } \\
\text { each of these, please tell me whether you, personally, have done any of } \\
\text { these things during the past year. If not, would you do this if you had } \\
\text { the chance: Refused to pay a tax or fee to government?" } \\
\text { - "I am now going to ask you about a range of different actions that } \\
\text { some people take. For each of the following, please tell me whether } \\
\text { you think the action is not wrong at all, wrong but understandable, or } \\
\text { wrong and punishable: Not paying the taxes they owe on their } \\
\text { income?" } \\
\text { - "For each of the following statements, please tell me whether you } \\
\text { disagree or agree: The police always have the right to make people obey } \\
\text { the law." } \\
\text { - "For each of the following statements, please tell me whether you } \\
\text { disagree or agree: The tax authorities always have the right to make } \\
\text { people pay taxes." } \\
\text { - "Regardless of whether you are able to pay them, are you required to } \\
\text { pay each of the following, or haven't you been able to find out about } \\
\text { this: License fees to local government, for example, for a bicycle, cart, } \\
\text { business or market stall?" } \\
\text { - "Regardless of whether you are able to pay them, are you required to } \\
\text { pay each of the following, or haven't you been able to find out about } \\
\text { this: Property rates or taxes?" } \\
\text { - "Regardless of whether you are able to pay them, are you required to } \\
\text { pay each of the following, or haven't you been able to find out about } \\
\text { this: If you have paid employment, are you required to pay an income } \\
\text { tax, that is, a tax deducted from your wages by your employer?" } \\
\text { - "Regardless of whether you are able to pay them, are you required to } \\
\text { pay each of the following, or haven't you been able to find out about } \\
\text { this: If you are self-employed, are you required to pay a tax on the } \\
\text { earnings from your business or job?" }\end{array}$ \\
\hline Size of the enterprise & Scale & $\begin{array}{l}\text { Survey item asking for the number of people working in the organization, } \\
\text { coded into three categories }(1=\text { low } / 3=\text { high })\end{array}$ \\
\hline Age of the enterprise & Scale & $\begin{array}{l}\text { Survey item asking for the age of the organization, coded into three } \\
\text { categories }(1=\text { low } / 3=\text { high })\end{array}$ \\
\hline $\begin{array}{l}\text { Venture's sales- vs. knowledge transfer- } \\
\text { focused activity }\end{array}$ & Dichotomous & $\begin{array}{l}\text { Survey item asking about the activities of the organization, coded into a } \\
\text { dichotomous variable }(0=\text { activities focused on sale of product or } \\
\text { service } / 1=\text { activities focused on knowledge transfer, training, and } \\
\text { consulting) }\end{array}$ \\
\hline
\end{tabular}

social enterprises $(0.10, p<.10)$, informality does not have a significant impact $(-0.09$, n.s. $)$, British colonization reduces this probability $(-2.25, p<.01)$, and strong ethnic group identities increase this probability $(0.30$, $p<.05$ ), when controlled for size, age, and the activity of the social venture.

Model 2 predicts the probability that the venture specifically targets poor or marginalized populations in their business models, our first measure of the choice of activities reflecting a social mission. In this case the fit indices suggest that the model also fits the data well and that it supports the predictions of our exploratory hypotheses.
A country's higher poverty level significantly increases the probability that social ventures will specifically target the poor in their business models $(0.08, p<.05)$, and strong ethnic group identities also increase this probability $(0.30, p<.01)$, when controlled for size, age, and the activity of the social venture, while informality and British colonization show no significant impact $(0.24$, n.s., and -0.25 , n.s., respectively).

Finally, model 3 predicts the probability that the venture includes the community in its decision making. The fit indices suggest that the model fits the data well, and the model supports the predictions of our exploratory 
TABLE 4

Descriptive Statistics and Correlation Table

\begin{tabular}{|c|c|c|c|c|c|c|c|c|c|c|c|c|c|c|c|}
\hline Variable & $N$ & Mean & Min & $\operatorname{Max}$ & SD & 1 & 2 & 3 & 4 & 5 & 6 & 7 & 8 & 9 & 10 \\
\hline $\begin{array}{l}\text { 1. Self-perception as a } \\
\text { social enterprise }\end{array}$ & 307 & 0.45 & 0.00 & 1.00 & 0.50 & 1.00 & & & & & & & & & \\
\hline $\begin{array}{l}\text { 2. Specific targeting } \\
\text { of the poor }\end{array}$ & 384 & 0.41 & 0.00 & 1.00 & 0.49 & $0.53 * * *$ & 1.00 & & & & & & & & \\
\hline $\begin{array}{l}\text { 3. Inclusion of the community } \\
\text { in important decisions }\end{array}$ & 239 & 0.30 & 0.00 & 1.00 & 0.46 & $0.30 * * *$ & 0.19 & 1.00 & & & & & & & \\
\hline 4. Human Poverty Index & 374 & 28.79 & 9.50 & 46.80 & 4.80 & $0.19 * * *$ & $0.20 * * *$ & $0.14^{* *}$ & 1.00 & & & & & & \\
\hline 5. British colonization & 375 & 0.82 & 0.00 & 1.00 & 0.38 & $-0.25 * * *$ & -0.08 & -0.04 & $-0.21 * * *$ & 1.00 & & & & & \\
\hline 6. Ethnic identity & 355 & 8.43 & 3.00 & 14.00 & 2.33 & 0.03 & $0.14 * *$ & $0.14^{* *}$ & 0.06 & $0.29 * * *$ & 1.00 & & & & \\
\hline 7. Informality & 358 & 0.00 & -0.87 & 2.21 & 1.00 & $0.16^{* *}$ & $0.23 * * *$ & 0.11 & $0.24 * * *$ & $-0.16^{* * *}$ & $0.10^{*}$ & 1.00 & & & \\
\hline 8. Size of the venture & 235 & 1.68 & 1.00 & 3.00 & 0.61 & $0.20 * * *$ & $0.26 * * *$ & $0.12^{*}$ & 0.08 & -0.05 & 0.01 & $0.21 * * *$ & 1.00 & & \\
\hline 9. Age of the venture & 327 & 2.13 & 1.00 & 3.00 & 0.71 & -0.03 & 0.06 & -0.03 & 0.04 & 0.06 & 0.07 & -0.03 & $0.28 * * *$ & 1.00 & \\
\hline $\begin{array}{l}\text { 10. Venture's sales- vs. knowledge } \\
\text { transfer-focused activity }\end{array}$ & 384 & 0.47 & 0.00 & 1.00 & 0.50 & $0.13^{* *}$ & 0.29 ** * & 0.08 & 0.05 & 0.01 & -0.03 & 0.07 & 0.03 & 0.03 & 1.00 \\
\hline
\end{tabular}

Significance levels: $* * *=<.01 / * *=<.05 / *=<.1$.

hypotheses. A country's higher poverty level significantly increases the probability that social ventures will include the community in their decision making $(0.08$, $p<.10$ ), and strong ethnic group identities also increase this probability $(0.20, p<.01)$, when controlled for informality, size, age, and the activity of the social venture, while informality and British colonization show no significant impact (0.01, n.s., and -0.64 , n.s., respectively). Interestingly, our results suggest that informality does not significantly affect self-perception or the choice of activities of the venture, as predicted, although caution is needed when interpreting this result, given the inherently difficult task of measuring informality and our novel multi-item operationalization.

Among control variables, both the fact that the venture has an activity that focuses on knowledge transfer and training (as opposed to sales) and the size of the venture have a significant and positive effect on the three dimensions of social entrepreneurship (albeit with variations in significance levels).

\section{Limitations}

Of course, this exploratory study, like any academic endeavor, has limitations. In particular, the approach adopted in this research reflects its exploratory nature, and, more generally, the difficulty associated with collecting data on African firms. Constraining factors included the absence of comprehensive, up-to-date, and readily available datasets and the difficulty of visiting potential social enterprises in 19 countries characterized by poor infrastructure. As a result, we adapted the data-collection strategies to a certain extent to reflect the characteristics of a nontraditional environment, as recommended by several scholars (Kriauciunas et al., 2011).

Our approach may be insightful for other scholars pursuing empirical research in such contexts.

First, we made efforts to disseminate information about the research and participation in the survey beyond online forums and through e-mails, to reach a

TABLE 5

Binomial Logistic Regression Models

\begin{tabular}{|c|c|c|c|}
\hline & $\begin{array}{c}\text { Model } 1 \\
\text { DV = Self-perception as a } \\
\text { social enterprise }\end{array}$ & $\begin{array}{c}\text { Model } 2 \\
\text { DV = Business model that specifically } \\
\text { targets the poor }\end{array}$ & $\begin{array}{c}\text { Model } 3 \\
\mathrm{DV}=\text { Inclusion of the community } \\
\text { in decision-making }\end{array}$ \\
\hline Intercept & $-3.83 * *$ & $-6.18^{* * *}$ & $-4.99 * * *$ \\
\hline Level of poverty & $0.10^{*}$ & $0.08 * *$ & $0.08^{*}$ \\
\hline Informality & -0.09 & 0.24 & 0.01 \\
\hline British colonization & $-2.25 * * *$ & -0.25 & -0.64 \\
\hline Ethnic identity & $0.30 * *$ & $0.20 * * *$ & $0.20 * * *$ \\
\hline Size of the venture & $0.88 * *$ & $1.05 * * *$ & 0.54 \\
\hline Age of the venture & $-0.54^{*}$ & -0.10 & -0.12 \\
\hline $\begin{array}{l}\text { Venture's sales- vs. knowledge } \\
\text { transfer-focused activity }\end{array}$ & $0.88^{* *}$ & $1.40^{* * *}$ & 0.29 \\
\hline $\mathrm{LR}$ & $34.72 * * *$ & $59.80 * * *$ & $20.21 * * *$ \\
\hline Score & $29.43^{* * *}$ & $53.37 * * *$ & $20.67 * * *$ \\
\hline Wald chi-square (df) & $23.29 * * *(7)$ & $41.75^{* * *}(7)$ & $16.33^{* *}(7)$ \\
\hline
\end{tabular}

Significance levels: $* * *=<.01 / * *=<.05 / *=<.1$. 
broader set of potential respondents. Advertisements were placed in national and regional newspapers, for instance, and phone calls were made to potential participants in Kenya and South Africa, while the project was also publicized on radio and through interaction with regional academic and practitioner networks. This approach helped to reduce, albeit not completely, the bias toward larger, more formal, urban-based, and internationally connected social enterprises that results from an Internet-based instrument. Nevertheless, the representation of small and micro social enterprises, such as those often operating in rural areas and on the edges of, or fully within, the informal economy, may be limited for some countries. Such enterprises are an important component in the landscape of social entrepreneurship in Africa and require further attention in future research.

Second, collecting data in several African countries inevitably leads to uneven coverage among countries, due to access to respondents and, more generally, the quality of infrastructure. As a result, it was easier to collect data in Kenya and South Africa than in unstable and often post-conflict countries such as Angola, Burundi, and the Democratic Republic of the Congo (Kolk \& Lenfant, 2015). Similarly, language barriers can pose a challenge when collecting data in sub-Saharan Africa, and it was not possible to provide a translated version of the questionnaire for all languages spoken across the region. Furthermore, certain languages have positive or negative connotations, adding another layer of complexity. For example, in the eastern part of the Democratic Republic of the Congo, certain versions of Kiswahili have been associated with the language of slave traders for a long time (Stigand, 1915) and can lead to biased responses even if the researcher speaks the language. Future research in the area may benefit from deeper collaborations with local scholars who have a better understanding of these nuances. 